\title{
Sosialisasi bahaya dan upaya pencegahan infeksi corona virus disease (COVID-19) di Kelurahan Koja, Jakarta Utara
}

\author{
Khariri 1,2* \\ Kementerian Kesehatan RI, Jakarta, Indonesia \\ 2Pengurus Daerah Keluarga Alumni Universitas Gadjah Mada DKI Jakarta, Jakarta, Indonesia
}

1Pusat Penelitian dan Pengembangan Biomedis dan Teknologi Dasar Kesehatan, Badan Penelitian dan Pengembangan Kesehatan,

\section{DOI: https://doi.org/10.29303/indra.v1i2.41}

\section{Article Info}

Received : 31-07-2020

Revised : 14-09-2020

Accepted: 24-09-2020

\begin{abstract}
Corona virus Disease (COVID-19) began with a report on December 31, 2019, in Wuhan City of China about pneumonia cluster cases that have not yet been identified. The number of COVID-19 cases has increased and has spread to almost all. The World Health Organization (WHO) has stated that COVID-19 is an international health problem and established as a pandemic. COVID-19 case in Indonesia was first reported on March 2, 2020, and spread in 34 provinces in Indonesia. Treatment and vaccination for the prevention of COVID-19 are still in the process of research. So far preventive measures such as maintaining distance, wearing masks, improving the immune system, and hand hygiene are expected to break the chain of transmission of COVID-19. The COVID-19 socialization aims to provide adequate information to the public about the dangers and efforts to prevent COVID-19 that can be carried out by individuals and the community. The socialization was held in Koja Village, North Jakarta on March 8, 2020. The activity was carried out by the Regional Management of Keluarga Alumni Universitas Gadjah Mada (KAGAMA) DKI Jakarta in collaboration with the Health Sub-Department and the Koja District Government, North Jakarta. The main part of the activity is the delivery of COVID19 material followed by interactive discussions between participants and resource persons. Individual and community prevention efforts are very important in reducing the number of cases and breaking the chain of transmission so that cases do not increase.
\end{abstract}

Keywords: COVID-19, community, empowerment, participation, prevention.

Citation: Khariri, K. (2020). Sosialisasi bahaya dan pencegahan infeksi coronavirus disease (COVID-19) di Kelurahan Koja, Jakarta Utara. INDRA: Jurnal Pengabdian kepada Masyarakat, 1(2), 37-40. doi: https://doi.org/10.29303/indra.v1i2.41

\section{Pendahuluan}

Infeksi Coronavirus Disease 2019 (COVID-19) disebabkan oleh Severe Acute Respiratory Syndrome Coronavirus 2 (SARS-CoV-2) yang merupakan virus corona jenis baru yang menginfeksi manusia dan belum pernah diidentifikasi sebelumnya (Shi et al., 2020). Sebelumnya telah ada dua jenis virus corona yang dapat menimbulkan gejala berat, seperti Middle East Respiratory Syndrome (MERS) dan Severe Acute
Respiratory Syndrome (SARS). Pada awal Desember 2019, Coronavirus Disease (COVID-19) pertama kali terjadi di Kota Wuhan Provinsi Hubei, Tiongkok. Dari hasil identifikasi sumber infeksi, didapatkan virus corona jenis baru yang belum pernah ada sebelumnya (Velavan \& Meyer, 2020). Center of Disease Control (CDC) memberi nama virus tersebut sebagai 2019 novel coronavirus (2019-nCoV). Badan Kesehatan Dunia (World Health Organization/WHO) sendiri menyebut virus tersebut dengan Severe Acute Respiratory Syndrome 
Coronavirus-2 (SARS-CoV-2) dan nama penyakitnya dinamakan Coronavirus Disease 2019 (COVID-19) (Paules, Marston, \& Fauci, 2020).

Kasus COVID-19 semakin bertambah banyak dan telah menyebar hampir ke semua negara sehingga menjadi masalah kesehatan internasional. Berdasarkan situasi global, pada tanggal 11 Maret 2020 WHO akhirnya menetapkan COVID-19 sebagai pandemi (Baloch, Zheng, \& Pei, 2020). Kasus konfirmasi COVID19 pertama di Indonesia dilaporkan pada tanggal 2 Maret 2020 (Syafrida \& Hartati, 2020). Data terakhir per tanggal 30 Juli 2020 dilaporkan jumlah kasus terkonfirmasi sebanyak 106.336 dengan jumlah pasien meninggal sebanyak 5.058 (Gugus Tugas Percepatan Penanganan COVID-19, 2020).

Kasus COVID-19 telah menyebar di seluruh provinsi di Indonesia dan jumlahnya terus meningkat. Hal ini berdampak pada bidang politik, ekonomi, sosial, budaya, pertahanan dan keamanan, serta kesejahteraan masyarakat di Indonesia (Syafrida \& Hartati, 2020). Pemerintah telah menetapkan COVID-19 sebagai salah satu penyakit yang menimbulkan Kedaruratan Kesehatan Masyarakat (KKM) dan menetapkan KKM COVID-19 di Indonesia sehingga wajib dilakukan upaya penanggulangan. Penyebaran yang luas, korban dan kerugian yang banyak, serta dampak pada bidang sosial ekonomi yang luas di Indonesia, sehingga pemerintah menyatakan bahwa pandemi COVID-19 sebagai bencana nasional (Keputusan Presiden, 2020).

Upaya untuk pengobatan dan vaksinasi untuk menanggulangi infeksi COVID-19 masih dalam proses penelitian (Zendrato, 2020). Tindakan pencegahan yang optimal diharapkan dapat menekan laju pertambahan kasus dan memutus rantai penularan. Langkah ini memerlukan peran serta dari semua komponen baik pemerintah maupun masyarakat. Peran serta masyarakat dengan mematuhi protokol kesehatan yang telah ditentukan oleh pemerintah atau tenaga kesehatan merupakan salah satu hal yang harus diperhatikan. Masyarakat perlu diberikan informasi yang memadai mengenai bahaya dan upaya pencegahan yang dapat dilakukan oleh individu dan masyarakat (Mariyani, 2020). Atas dasar hal tersebut maka dilakukan sosialisasi tentang COVID-19 terhadap masyarakat awam, salah satunya dilakukan di Kelurahan Koja Jakarta Utara yang merupakan daerah binaan Keluarga Alumni Universitas Gadjah Mada (KAGAMA) DKI Jakarta. Sosialisasi ini bertujuan agar masyarakat memahami secara benar dalam menyikapi virus corona.

\section{Metode}

Sosialisasi Covid-19 dilakukan di Ruang Publik Terpadu Ramah Anak (RPTRA) Sindang, Kelurahan
Koja, Kecamatan Koja, Jakarta Utara. Kegiatan dilakukan pada hari Minggu tanggal 8 Maret 2020 dan dilaksanakan oleh Pengurus Daerah Keluarga Alumni Universitas Gadjah Mada (KAGAMA) DKI Jakarta bekerjasama dengan Dinas Kesehatan DKI Jakarta, Puskesmas Koja serta Kecamatan Koja. Peserta yang hadir dalam kegiatan tersebut adalah Sekretaris Kecamatan Koja, Zaenal Nasution, Lurah Koja, Frimelda Novarita beserta Aparatur Sipil Negara (ASN) Kelurahan Koja, perwakilan pengurus Rukun Tetangga (RT), Rukun Warga (RW), Lembaga Musyawarah Kelurahan (LMK), Forum Kewaspadaan Dini Masyarakat (FKDM), kader dasawisma, jumantik serta anggota kader Pemberdayaan Kesejahteraan Keluarga (PKK).

Kegiatan sosialisasi dilakukan melalui pemaparan oleh narasumber dan dilanjutkan tanya jawab dengan peserta. Alat dan bahan yang digunakan antara lain proyektor, layar proyektor, pointer, alat pengeras suara dan leaflet berisi bahan sosialisasi. Pengumpulan data dilakukan dengan observasi dan dokumentasi kegiatan. Analisis data dilakukan secara deskripsi yang menggambarkan proses kegiatan.

Rangkaian kegiatan terdiri dari beberapa tahapan, yaitu pembukaan, sambutan dari pihak Kecamatan Koja, sambutan dari Pengurus Daerah KAGAMA DKI Jakarta, penyampaian materi tentang COVID-19 meliputi sumber infeksi, gejala, cara penularan dan langkah-langkah pencegahan yang dapat dilakukan oleh individu dan masyarakat. Pada saat penyampaian sosialisasi juga diberikan kesempatan tanya jawab interaktif antara pemateri dengan peserta. Acara diakhiri dengan pemberian kenang-kenangan kepada pengisi acara dan foto bersama.

\section{Hasil dan Pembahasan}

Kegiatan sosialisasi pencegahan virus Corona atau penyakit COVID-19 dilakukan sebelum diberlakukan kewajiban penggunaan masker oleh pemerintah dan diterapkan Pembatasan Sosial Berskala Besar (PSBB) di DKI Jakarta. Kegiatan dilaksanakan pada hari Minggu tanggal 8 Maret 2020 yang dilakukan oleh Pengurus Daerah Keluarga Alumni Universitas Gadjah Mada (KAGAMA) DKI Jakarta bekerjasama dengan Sudin Kesehatan serta Pemerintah Kecamatan Koja, Jakarta Utara, bertempat di Ruang Publik Terpadu Ramah Anak (RPTRA) Sindang Raya, Kelurahan Koja, Jakarta Utara. Kegiatan dilaksanakan sekitar 3 jam dari pukul 08.00 sampai 11.00 WIB. Peserta yang hadir dalam kegiatan tersebut adalah Sekretaris Kecamatan Koja Zaenal Nasution, Lurah Koja Frimelda Novarita beserta Aparatur Sipil Negara (ASN) Kelurahan Koja, perwakilan pengurus RT, RW, 
LMK FKDM, kader dasawisma, jumantik serta anggota kader PKK.

Sebelum acara dimulai, peserta yang hadir mengisi daftar kehadiran terlebih dahulu. Acara dibuka oleh pembawa acara. Sebagai rangkaian pertama, disampaikan kata sambutan oleh pihak Kecamatan Koja yang pada kesempatan tersebut disampaikan oleh Bapak Zaenal Nasution selaku Sekretaris Kecamatan Koja. Pada sambutannya, disampaikan bahwa kegiatan sosialisasi bertujuan agar masyarakat memahami secara benar dalam menyikapi virus corona. Acara kemudian dilanjutkan dengan sambutan Pengurus Daerah KAGAMA DKI Jakarta yang disampaikan langsung oleh ketua, yaitu Ibu Meinarwati (Gambar 1).

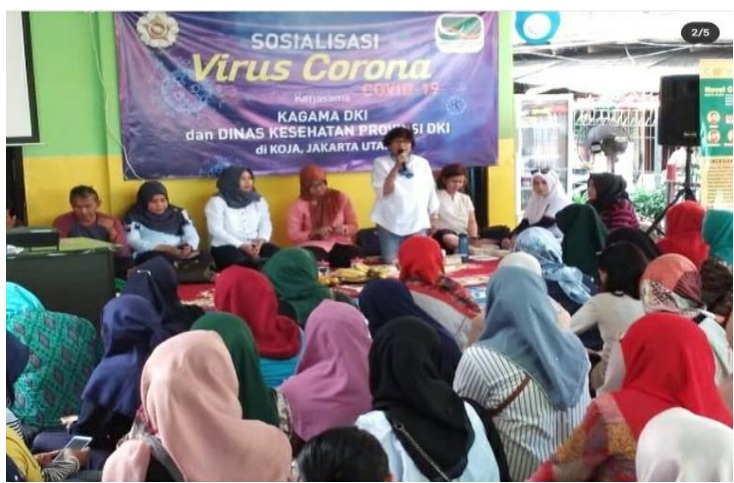

Gambar 1. Sambutan Pengurus Daerah KAGAMA DKI Jakarta

Bagian utama kegiatan yaitu penyampaian materi COVID-19 disampaikan oleh Dinas Kesehatan Provinsi DKI Jakarta (Gambar 2). Materi yang disampaikan pada sosialisasi tersebut antara lain apa itu penyakit COVID-19, penyebab, gejala, cara penularan dan upaya pencegahan yang dapat dilakukan oleh individu dan masyarakat. Setelah penyampaian materi dilanjutkan dengan diskusi interaktif antara peserta dengan narasumber. Bagian ini menjadi cara untuk mengukur keberhasilan penyampaian informasi dan pemahaman yang telah diterima oleh para peserta.

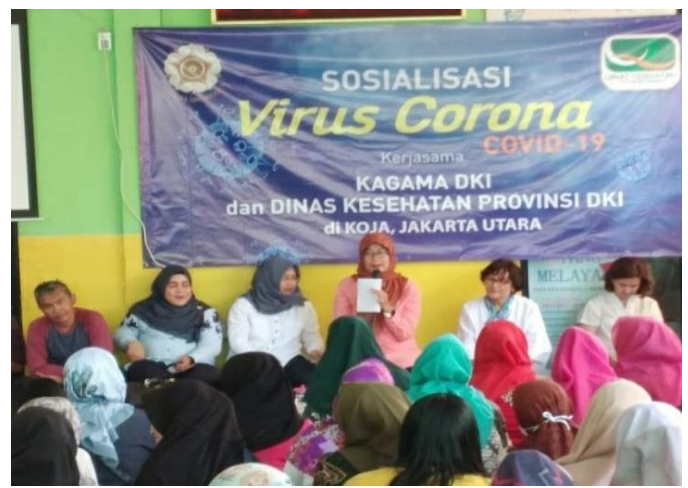

Gambar 2. Penyampaian materi sosialisasi COVID-19
Sejauh ini obat yang efektif untuk terapi infeksi COVID-19 masih belum tersedia. Pengobatan dan vaksinasi masih dalam proses penelitian sehingga upaya pencegahan yang dapat dilakukan secara individu dan masyarakat merupakan hal yang sangat penting. Kunci keberhasilan upaya penanggulangan COVID-19 sangat ditentukan oleh peran masyarakat. Untuk itu diperlukan peran serta dan kerja sama semua perangkat desa mulai dari tingkat RT, RW, dan kelurahan atau desa (Buana, 2020).

Upaya pencegahan yang dapat dilakukan oleh masyarakat mengacu pada Gerakan Masyarakat Hidup Sehat (Germas) melalui Perilaku Hidup Bersih dan Sehat (PHBS). Beberapa diantaranya adalah sering mencuci tangan menggunakan sabun dan air mengalir atau menggunakan hand sanitizer, menggunakan masker, menerapkan etika batuk dan bersin dengan benar, meningkatkan imunitas tubuh dengan cara aktivitas fisik atau olahraga, konsumsi gizi seimbang, suplemen vitamin, serta istirahat cukup. Untuk meminimalkan kontak antar individu yang berisiko menularkan, masyarakat harus membiasakan diri untuk menjaga jarak (sosial distancing) dan pembatasan interaksi fisik (physical distancing). Ketika berinteraksi dengan orang lain usahakan menjaga jarak minimal 1 meter, menghindari kerumunan/ keramaian (Syafrida \& Hartati, 2020).

Peran serta masyarakat dalam pencegahan COVID-19 dapat dilaksanakan dengan prinsip pemberdayaan masyarakat. Pemberdayaan masyarakat merupakan semua usaha yang dilakukan oleh seluruh komponen masyarakat dengan menggali setiap potensi yang ada pada masyarakat tersebut sehingga berdaya dan mampu berperan serta dalam mencegah penularan COVID-19. Pemberdayaan masyarakat dapat dimulai dari pendataan kesehatan anggota masyarakat di lingkungan RT, RW, atau kelurahan, mencari kemungkinan faktor penularan dan potensi wilayah yang ada (Kementerian Kesehatan, 2020).

Pemerintah melalui perwakilan di tingkat terkecil dapat melakukan sosialisasi program dan kebijakan pemerintah dalam upaya pencegahan COVID-19. Kegiatan sosialisasi COVID-19 merupakan salah satu bentuk kegiatan pemberdayaan masyarakat. Penyusunan rencana kegiatan di masyarakat seperti penyampaian informasi tentang COVID-19 dan edukasi cara-cara pencegahan serta pelaporan sebagai bentuk hasil sebagai bahan evaluasi dan monitoring tingkat pusat perlu banyak dilakukan (Mariyani, 2020).

Penyampaian informasi kepada masyarakat diharapkan dapat menggugah motivasi dalam ikut serta dalam upaya pencegahan. Masyarakat juga harus mengikuti dengan disiplin kebijakan pemerintah seperti tetap tinggal di rumah, tidak bepergian, tidak mudik, bekerja, ibadah dan belajar dari rumah, 
menerapkan etika batuk, membiasakan diri mencuci tangan dengan sabun dan air mengalir, menggunakan masker jika keluar rumah, menghindari berkumpul atau berkerumun, melakukan social distancing atau physical distancing saat keluar rumah. Jika keadaan sakit sebaiknya tidak mengunjungi orang tua atau lanjut usia. Masyarakat juga dapat mengambil peran untuk meneruskan informasi pencegahan COVID-19 dan saling mengingatkan sesama warga untuk menjaga kebersihan diri dan lingkungan dalam kehidupan sehari-hari. Penerapan protokol kesehatan dapat menjadi acuan dalam penerapan perilaku dan model kehidupan baru dalam jangka waktu yang panjang (Yunus \& Rezki, 2020).

\section{Simpulan}

Kegiatan sosialisasi bertujuan agar masyarakat mendapatkan informasi yang jelas tentang COVID-19 sehingga lebih waspada dan dapat melakukan upaya pencegahan secara individu, kelurga dan masyarakat. Pengobatan dan vaksinasi untuk infeksi COVID-19 masih dalam proses penelitian. Upaya pencegahan secara individu dan masyarakat merupakan hal yang sangat penting dalam menekan jumlah kasus dan memutus rantai penularan agar kasusnya tidak semakin meningkat. Perilaku dasar yang harus dan wajib dilakukan yaitu menjaga jarak, penggunaan masker, hand hygiene (mencuci tangan sesering mungkin, menggunakan hand sanitizer) dan perbaikan sistem imun. Adaptasi dengan kebiasaan baru harus dilakukan dengan disiplin. Masing-masing individu juga diharapkan untuk saling mengingatkan untuk menerapkan protokol kesehatan di berbagai sektor.

\section{Ucapan Terima Kasih}

Ucapan terima kasih disampaikan kepada Pengurus Daerah Keluarga Alumni Gadjah Mada (KAGAMA) DKI Jakarta dan Dinas Kesehatan Provinsi DKI Jakarta yang telah membantu memberikan penyuluhan COVID-19 kepada masyarakat di Kelurahan Koja, Jakarta Utara.

\section{Daftar Pustaka}

Baloch, S. M. A., Zheng, T., \& Pei, X. (2020). The coronavirus disease 2019 (COVID-19) pandemic. Tohoku Journal of Experimental Medicine, 250(4), 271278.

Buana, R. D. (2020). Analisis perilaku masyarakat Indonesia dalam menghadapi pandemi COVID-19 dan kiat menjaga kesejahteraan jiwa.Salam; Jurnal Sosial Dan Budaya Syar-I, 7(3), 217-226.

Gugus Tugas Percepatan Penanganan COVID-19. (2020). Infografis COVID-19. Jakarta: Gugus Tugas
Percepatan Penanganan COVID-19.

Kementerian Kesehatan. (2020). Pedoman Pemberdayaan Masyarakat dalam Pencegahan COVID-19 di RT/RW/Desa. Jakarta: Kementerian Kesehatan RI.

Keputusan Presiden. (2020). Penetapan bencana nonalam penyebaran corona virus disease 2019 (COVID-19) sebagai bencana nasional. Jakarta: Sekretariat RI.

Mariyani, A. (2020). Menumbuhkan kesadaran masyarakat Indonesia untuk memutuskan rantai penyebaran wabah COVID-19. Jurnal Global Citizen, 2(1), 51-62.

Paules, C. I., Marston, H. D., \& Fauci, A. S. (2020). Coronavirus infections - More than just the common cold. American Medical Association, 323(8), 707-708.

Shi, Y., Wang, G., Cai, X., Deng, J., Zheng, L., Zhu, H., Zheng, M., Yang, B., \& Chen, Z. (2020). An overview of COVID-19. J Zhejiang Univ-Sci B (Biomed $\mathcal{E}$ Biotechnol), 21(5), 343-360.

Syafrida, S., \& Hartati, R. (2020). Bersama melawan virus covid 19 di Indonesia. Salam: Jurnal Sosial dan Budaya Syar-I, 7(6), 495-508.

Velavan, T. P., \& Meyer, C. G. (2020). The COVID-19 epidemic. Tropical Medicine and International Health, 25(3), 278-280.

Yunus, N. R., \& Rezki, A. (2020). Kebijakan pemberlakuan lock down sebagai antisipasi penyebaran corona virus COVID-19. Salam: Jurnal Sosial dan Budaya Syar-I, 7(3), 227-238.

Zendrato, W. (2020). Gerakan mencegah daripada mengobati terhadap pandemi COVID-19. Jurnal Education and Development, 8(2), 242-248. 